\title{
Enabling Criticality: A Top-down Bottom-up Approach to Using TED Talks in EAP Listening Classes
}

\author{
Adam Gyenes ${ }^{1}$, Ph.D. \& Luis F. Santos ${ }^{2}$, Ph.D. \\ ${ }^{1}$ Department of Sociology, Ryutsu Keizai University, Japan \\ (D)/0000-0002-5989-1798 \\ ${ }^{2}$ Institute of Curriculum and Instruction, Nanjing Normal University, China \\ (D)/0000-0003-3094-6588 \\ DOI: https://dx.doi.org/10.46679/978819484836311
}

\section{Abstract}

The use of TED talks in EAP has gained popularity in recent years and they are promoted through coursebooks as a means of simultaneously developing listening and critical thinking skills. However, a traditional comprehension approach to teaching listening; one that focuses on testing lower-order thinking skills through discrete questions may be inadequate as a gateway into a critical consideration of broader issues for second language learners. With the practical purpose of developing a teaching approach to using TED talks informed by current theory, the chapter begins with a consideration of how critical thinking processes and top-down and bottom-up listening processes can be integrated into a singular model. Based on this framework, a genre analysis of the TED talk is made by taking a learner's perspective in order to identify cognitive and affective barriers to listening that may restrict opportunities for critical thinking. In the discussion that follows, five activities are suggested for use with TED talks in listening classes that support top-down and bottom-up listening processes, and which set students up to analyse and evaluate the thesis and underlying structure of a TED talk, 
providing a solid foundation from which to approach discussion topics critically and reflectively.

Keywords: Critical thinking, English for academic purposes, second language listening, TED talks

\section{Introduction}

The use of TED talks has found popularity in university EAP classes, chiefly as a means of developing academic listening skills. Due to ease of access, their appropriate length, a large array of stimulating topics, clear diction, visual engagement, and the ability to replay sections or view subtitles and transcripts in multiple languages across platforms, they can be easily adapted to numerous teaching contexts. Their potential as part of an autonomous, experiential and social, modern learning experience (Owens \& Kadakia, 2016) extends their appeal beyond the convenience afforded by their ready availability. They are a distinct type of presentation, and arguably an emergent genre in their own right; one which blends "the sales pitch, the memoir, and the academic lecture" (Ludewig, 2017, p.1). Compared with traditional university lectures, TED talks have been shown to have lower Academic Vocabulary List (AVL) representation (Wingrove, 2017). This pseudo-academic tenor helps to make academic topics accessible and appealing, and several coursebooks ${ }^{1}$ adapt TED talks and promote them in the EAP context as an authentic means of providing listening input while developing critical thinking skills needed to engage with current, real-world discussion topics.

Yet certain issues arise from linking listening with critical thinking and discussion, for without denying that TED speakers are 'authentic' or 'natural' in their language use, their talks are at the same time: "highly prepared, perfectly delivered oral performances"

\footnotetext{
${ }^{1}$ For example, the ' $21^{\text {st }}$ Century Reading' series' published by National Geographic Learning (Blass et al., 2016).
} 


\section{This is a limited preview of the chapter.}

To read the full-text chapter, get access by purchasing this chapter or consider buying the complete book. If your library has subscription to EBSCOhost, the chapter including other chapters of the book can be accessed through your library.

This chapter is a part of the book, 'Development of Innovative Pedagogical Practices for a Modern Learning Experience' ISBN (paperback): 978-81948483-6-3; ISBN (ebook): 978-81-948483-7-0

Book DOI: https://dx.doi.org/10.46679/9788194848363

Available via CSMFL Bookstore, Amazon, Google Play Books, EBSCOhost \& EBSCO eBooks 
arguments to the thesis can you think of?"; or "Was there anything important to consider that the speaker did not talk about?" These are questions that challenge students in core critical thinking markers of breadth, depth of thought, and intellectual accuracy (Facione \& Gittens, 2016, pp.321-322; Fisher, 2011, pp. 60, 84-86; Halpern, 2014, pp. 246256). Speaking activities can also be planned around similar discussion prompts.

\section{Conclusion}

In this chapter we presented an integrated model employing top-down and bottom-up listening, and critical thinking processes. We conceptualised and analysed TED talks as a genre to demonstrate one way to support learners in the listening classroom environment. Indeed, a need for empirical work exploring our proposed framework through investigations of the challenges faced by learners in critically approaching TED talks may shed light on the efficacy of our suggested teaching interventions. In presenting these five teaching activities, we have highlighted how they can merge the linguistic goal of helping learners to better understand TED talks with furthering critical thinking development. The two processes need not be differentiated in the classroom, and rather than 'tacking on' critical thinking activities to the end of a language lesson, it can be involved throughout topdown and bottom-up listening activities, as it is inherently involved in these listening processes. By planning the listening component of lessons around top-down and bottom-up, learners can be better prepared to discuss the broader issues.

\section{References}

Adichie, C. (2009, July). The danger of a single story [Video file]. Retrieved from:

https://www.ted.com/talks/chimamanda_ngozi_adichie_the_dan 
ger_of_a_single_story?utm_campaign=tedspread\&utm_medium $=r$ eferral\&utm_source=tedcomshare

Anderson, L., Krothwohl, D., Airasian, P., Cruikshank, K., Mayer, R., Pintrich, P., \& Wittrock, M. (2001). A taxonomy for learning, teaching, and assessing a revision of Bloom's Taxonomy of educational objectives. Longman.

Astika, G., \& Kurniawan, A. (2019). The challenges of using TED Talks as authentic resources of academic listening for EFL university students. Indonesian Journal of Applied Linguistics, 9, 589-598. doi: 10.17509/ija l.v9i3.23209

Bali, M. (2015). Critical thinking through a multicultural lens: Cultural challenges of teaching critical thinking. In M. Davies \& R. Barnett (Eds.), Palgrave handbook of critical thinking in higher education (pp. 317-334). Palgrave Macmillan.

Blass, L., Wisniewska, I., \& Vargo, M. (2016). 21st century reading: Creative thinking and writing with Ted Talks 3. National Geographic Learning, Cengage Learning.

Brazil, D., Coulthard, M., \& Johns, C. (1981). Discourse intonation and language teaching. Longman.

Brown, S. R. (2011). Listening myths: Applying second language research to classroom teaching. University of Michigan Press.

Cauldwell, R. (2013). Phonology for listening: Teaching the stream of speech. Speech in Action.

Chang, Y., \& Huang, H. (2015). Exploring TED Talks as a pedagogical resource for oral presentations: A corpus-based move analysis. English Teaching and Learning,39(4), 29-62. doi:10.6330/ETL.2015.39.4.02

Cook, G. (1997) Key concepts in ELT: Schemas. ELT Journal51(1), 86.https://doi.org/10.1093/elt/54.1.98

Cross, J. (2010). Raising L2 listeners' metacognitive awareness: A sociocultural theory perspective. Language Awareness, 19(4), 281297. https://doi.org/10.1080/09658416.2010.519033 
Cutler, A., \& Clifton, C. (1999). Comprehending spoken language: A blueprint of the listener. In C. Brown \& P. Hagoort (Eds.), The neurocognition of language. Oxford University Press.

Ennis, R. H. (1987) A conception of critical thinking with some curriculum suggestions, APA Newsletter on Teaching Philosophy, pp. 1-5.

Facione, P. A. (1990). Critical thinking: A statement of expert consensus for purposes of educational assessment and instruction executive summary “The Delphi Report.”The California Academic Press, 423(c), $1-19$.

Facione, P. A., \& Gittens, C. A. (2016). Think critically. Pearson.

Fairclough, N. (2005). Analyzing discourse: Textual analysis for social research. Routledge.

Field, J. (1999). Key concepts in ELT: 'Bottom-up' and 'Top-down'. ELT Journal,53(4), 338-340. doi:https://doi.org/10.1093/eltj/53.4.338

Field, J. (2010). Listening in the language classroom. Cambridge University Press.

Field, J. (2019). Second language listening: Current ideas, current Issues. In J. W. Schwieter,\& A. G. Benati (Eds.), The Cambridge handbook of language learning (pp. 283-319). Cambridge University Press.

Fisher, A. (2011). Critical thinking: An introduction (2nd ed.). Cambridge University Press.

Gao, B. (2015). Empirical study on relationship between English majors' critical thinking skills and their second language proficiency. Journal of Jiangsu University of Science and Technology, 15(4), 98-103.

Gee, J. P. (2014). How to do discourse analysis: A toolkit. Routledge.

Harbisson, N. (2012, June). I listen to color [Video file]. Retrieved from: https://www.ted.com/talks/neil_harbisson_i_listen_to_color?lan guage $=$ en

Halpern, D. F. (2014). Thought and knowledge: An introduction to critical thinking (5th ed.). Taylor \& Francis. 
Hedge, T. (2008). Teaching and learning in the language classroom. Oxford University Press.

Hyon, S. (2018). Introducing genre and English for specific purposes. Routledge.

Levelt, W. (1995). Speaking from intention to articulation. MIT Press.

Ludewig, J. (2017). TED Talks as an emergent genre. CLCWeb: Comparative Literature and Culture,19(1). doi:10.7771/1481-4374.2946

Lynch, T. (2009). Teaching second language listening. Oxford University Press.

Manolo, E., \& Sheppard, C. (2016). How might language affect critical thinking performance? Thinking Skills and Creativity, 21: 41-49.

Owens, L. M. D., \& Kadakia, C. (2016, April 26). Is reading a book a modern learning method? The Association for Talent Development. https://www.td.org/insights/is-reading-a-book-amodern-learning-method

Paton, M. (2008). Reflective journals and critical thinking. InJ. V.RijHeyligers, S. Carter, \&J. Buxton (Eds.), Intercultural communications across university settings: $m y$ ths and realities: referreed proceedings of the 6th Communication Skills in University Education Conference (pp. 201-209). Pearson Education.

Paul, R., \& Elder, L. (2012). Critical thinking: Tools for taking charge of your learning and your life (3rd ed.). Pearson Education.

Powell, M. (2018). Presenting in English: how to give successful presentations. Cengage Learning.

Richards, J. (1990). The Language teaching matrix: Curriculum, methodology, and materials. Cambridge University Press.

Robinson, K. (2006, February). Do schools kill creativity? [Video file].

Retrieved from:

http://www.ted.com/talks/lang/en/ken_robinson_says_ schools_kill_creativity.html

Rost, M. (2016). Teaching and researching listening. Routledge. 
Scriven, M., \& Paul, R.(1987). Defining critical thinking, Draft statement written for the National Council for Excellence in Critical Thinking Instruction. http://www.criticalthinking.org/pages/defining-criticalthinking/766

Siegel, J. (2015). Exploring listening strategy instruction through action research. Palgrave Macmillan.

Swales, J. (1990). Genre analysis: English in academic and research settings. Cambridge University Press.

Takaesu, A. (2014). TED Talks as an extensive listening resource for EAP students. Language Education in Asia, 4(2), 150-162. doi:10.5746/leia/13/v4/i2/a05/takaesu

Thorn, S. (2012). Debunking authentic listening. Modern English Teacher, 21(2): 65-69.

Tian, J., \& Low, G. D. (2011). Critical thinking and Chinese university students: A review of the evidence. Language, Culture and Curriculum, 24(1), 61-76. doi:10.1080/07908318.2010.546400

Vandergrift, L. (2004). Listening to learn or learning to listen? Annual Review of Applied Linguistics, 24, 3-25. doi:10.1017/s0267190504000017

Vandergrift, L., \& Goh, C. (2012). Teaching and learning second language listening: Metacognition in action. Routledge.

Wajnryb, R. (1990). Resource books for teachers: Grammar dictation. Oxford University Press.

White, G. (2010). Listening. Oxford University Press.

Wingrove, P. (2017). How suitable are TED talks for academic listening? Journal of English for Academic Purposes,30, 79-95. doi:10.1016/j.jeap.2017.10.010 


\section{About the authors}

Adam Gyenes holds a PhD in Transformative Education from Osaka University and an MA in Japanese Studies from Sheffield University. His main research interest is critical thinking in discourses and practices related to the internationalization of university education in Japan. Other interests include qualitative research methods, EMI, EAP and Language teaching, and he has contributed to and authored English textbooks. He teaches at Ryutsu Keizai University, Chiba, Japan.

Luis F. Santos holds a PhD in Education. He carries out research for the Institute of Curriculum and Instruction of Nanjing Normal University (China). He has conducted research on critical thinking instruction as part of his doctoral studies emphasizing the ethical and civic dimensions of critical thought. His current research interests and projects are focused on the multiple dimensions of Critical Thinking and their implementation in the classroom through dialogical pedagogies and formative assessment. 
